\title{
多結晶ダイヤモンド砥粒の形状と研磨特性
}

\section{Effect of Polycrystal Diamond Grain Shape on Lapping Characteristics}

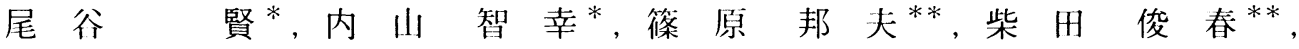 \\ Masaru OTANI, Tomoyuki UCHIYAMA, Kunio SHINOHARA, Toshiharu SHIBATA, \\ 荒堀弘造 ${ }^{* *}$, 䅖山勝 ${ }^{* * *}$, 平井明彦*** \\ Kouzou ARAHORI, Masaru AKIYAMA, Akihiko HIRAI
}

\begin{abstract}
The effects of particle size and shape of artificial polycrystal diamond grain were studied. The relationship between particle size and lapping characteristics was explained by a stress - strain relation between the work and lapping grain, and it was confirmed that the lapping rate is proportional to the square of particle size and the surface roughness is proportional to it. Furthermore, it is possible to prepare lapping grain with a high lapping rate and small surface roughness by modification of particle shape. An empirical formula which estiamtes the lapping rate from particle shape was obtained.
\end{abstract}

Key Words : Lapping Rate, Surface Roughness, Polycrystal Diamond, Particle Shape.

\section{1. 緒言}

近年，粉体材料に対するユーザーのニーズは，用途 の高機能化に伴いこれまでの組成あるいは粒子径分布 などから粒子個々の形状や表面性状など，より微視的 な粒子物性の評価や調整という厳しいものになってき ている。

粒子形状による粉体の力学特性への影響に関して は，粒子径と同椂に重要な幾何学的因子にも関わら ず，評価すべき形状の特徵が多様であり，また粉体の 調製加工技術においても，粒子レベルでの形状調製が 困難なため, それらの関係についての報告 ${ }^{1 \text { (5) }}$ は数少

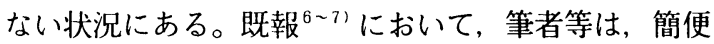
で且つマクロな形状の特徴を十分に表現できる評価法 として, 投影粒子像輪郭座標をフーリ工級数展開し指

1999年 2 月 17 日受付

* 北海道立工業試験場資源エネルギー部

(テ060-0819 札幌市北区北19条西11丁目) TEL 011-681-1697

Department of Resources and Energy, Hokkaido Industrial Research Institute

(Nishi 11. Kita 19, Kita-ku, Sapporo-shi, 060-0819)

** 北海道大学大学院工学研究科

(宁060-8628 札幌市北区北13条西 8丁目)

Division of Materials Science and Engineering, Graduate School of Engineering. Hokkaido University

***踭イズミテック

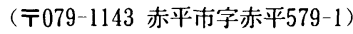

IZUMI Technology Co., Ltd.

(Akabira 579-1 Akabira-shi, 079-1143)
数化する方法（以下，フーリエ楕円近似法）を提案 し，粒子形状と粉体物性の関係について明らかにし， 粒子形状は静的な物性に対してより大きな効果を示す ことを報告した。

本研究では, ハードディスク, 磁気ディスク等の電 子機器部品の高性能化に不可欠な精密研磨加工に用い られる人工多結晶ダイヤモンド砥粒の性能向上を目的 に，粉体の一次物性である粒子径及び粒子形状に着目 し，研磨特性との関係について実験を行い，研磨機構 の検討を行った。なお，今中らは，遊離砥粒の研磨速 度之砥粒及び被研磨材の物性, 研磨 (操作) 条件等之 の関係を広範に数式化しているが，その際，砥粒形状 は球形としている ${ }^{8)}$ 。

\section{2. 実験}

\section{1 試 料}

供試試料は, 粒子径の異なる 3 試料及び形状の異な る多結晶ダイヤモンド（㑣イズミテック製）4試料を 用いた。Table 1 及び 2 に各試料の物性を示す。

\section{2 装置および方法}

\section{2.1 粒度測定}

粒子径は、レーザ一回折散乱法（SALAD 2000，(株) 島津製作所製）および電気的検知法（Multisizer II， Coulter 製）によって計測した。また，粒子径分布の 均一性は, 電気的検知法による通過分率 0.25 と 0.75 の比を指標として評価を行った。 
Table 1 Properties of diamond grain of different sizes

\begin{tabular}{l|c|c|c}
\hline Sample name & $\mathrm{a}$ & $\mathrm{b}$ & $\mathrm{c}$ \\
\hline Median diameter $(\mu \mathrm{m})$ & 0.722 & 1.458 & 2.585 \\
\hline Sharpness index $(-)$ & 0.68 & 0.68 & 0.72 \\
\hline Particle density $\left(\mathrm{g} / \mathrm{cm}^{3}\right)$ & & 3.52 & \\
\hline
\end{tabular}

Table 2 Properties of diamond grain of different shapes

\begin{tabular}{l|c|c|c|c}
\hline Sample name & A & B & C & D \\
\hline Median diameter $(\mu \mathrm{m})$ & 2.889 & 2.868 & 2.823 & 2.808 \\
\hline Sharpness index $(-)$ & 0.698 & 0.703 & 0.716 & 0.722 \\
\hline Particle density $\left(\mathrm{g} / \mathrm{cm}^{3}\right)$ & \multicolumn{4}{|c}{3.52} \\
\hline $\begin{array}{c}\text { Shape index, } k(-) \\
\text { Coefficient of } \\
\text { variation, } C_{\mathrm{vr}}(-)\end{array}$ & 0.702 & 0.725 & 0.786 & 0.803 \\
\hline
\end{tabular}

\section{2. 2 形状測定}

各試料は電子顕微鏡によって撮影後, その粒子像写 真を CCD カメラ (KP-210 形, HITACHI 製) で画像 解析装置 (LUZEX3U, ニレコ製) に取り込み, 二值 化後その輪郭座標を検出した。測定粒子数は 1 試料に つき 20 個とし， 15000 倍で撮影したものを用いた。

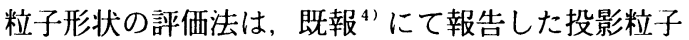
像輪郭の $\mathrm{x}, \mathrm{y}$ 座標をそれぞれフーリエ級数展開し， その第 1 項目の係数のみにより求められた近似棈円の 短長軸比を形状指数 $k$ とし, さらに，この近似棈円 と粒子像の輪郭座標との半径方向での標準偏差を近似 楕円と等周長円の半径 $r_{\mathrm{c}}$ で除した変動係数 $C_{\mathrm{vr}}$ 值 を，セミミクロな表面の凹凸度として用いた。すなわ ち,

形状指数 $k$ : 粒子投影像全体の巨視的な形状の指数 粒子凹凸度 $C_{\mathrm{vr}}$ : 粒子像輪郭の凹凸等を考慮した準 微視的な形状の指数

\section{2.3 研磨試験}

研磨装置は, 精密平面ラップ盤（Model LP-15, ラップマスター社製）を用いた。

本装置は, 時計方向に回転する研磨定盤上に, 反時 計方向に回転する被研摩材ワークを固定した円形ホル ダーを一定荷重にて接触させ, その接触界面に一定濃 度の砥粒が分散した水性スラリーを噴霧し, 被研摩材 の研磨特性を測定するものである。なお，被研摩材 は，粒子径の試験にはダイヤモンド砥粒の研磨試験と して一般的に用いられるサファイヤガラスを, 粒子形
状の試験にはその研磨速度への影響を精度良く評価す るためにサファイヤに比へ硬度の低いフェライトを用 いた。各実験の研磨条件を下記に示す。

(a) 粒子径と研磨特性

ワーク：サファイヤガラス, ラップ盤 : Kemmet 銅, ワーク荷重 : $137.2 \mathrm{kPa}$, 回転数 : $30 \mathrm{rpm}$, スラ リ一濃度 : $1.6 \mathrm{~g} / \mathrm{l}$

(b) 粒子形状と研磨特性

ワーク：フェライト, ラップ盤: Kemmet 銅, ワー ク荷重 : $28.4 \mathrm{kpa}$, 回転数 : $90 \mathrm{rpm}$, スラリー濃度 : $1.6 \mathrm{~g} / l$

\section{2.4 研磨特性の評価法}

研磨特性として被研摩材の表面粗さ，および研磨速 度について測定を行った。

表面粗さは，表面粗さ計（SE-30D，(梀小坂研究所 製) で平均粗さ $R a$ を測定し, 研磨速度は, 被研摩材 の単位時間当たりに研磨される厚さで評価し，その厚 さは厚さゲージ（リニアゲーシ，(侏ミツトヨ製）で測 定した。被研摩材の表面粗さ及び研磨速度は, 1 試料 につき 24 点測定し，その平均値を用いた。

\section{3. 実験および考察}

\section{1 粒子径による研磨特性への効果}

Fig. 1 に示す様に, 粒子径の増加に伴い研磨速度は 向上し，両者の関係は 2 次式により近似できた。

これは, 研磨過程における被研摩材と砥粒間におけ る応力 $\sigma$-歪み $\varepsilon$ の関係に基づくものと考えられる。 


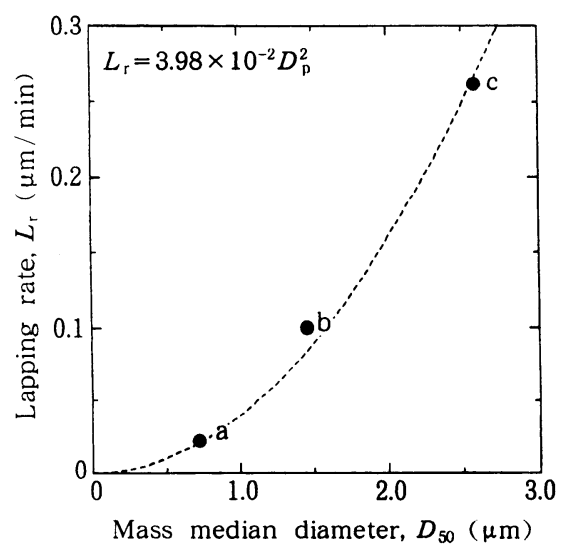

Fig. 1 Relationship between $D_{\bar{x}(1)}$ and lapping rate

一定砥粒体積濃度の研磨スプレーでは, 被研摩材と定 盤間に存在する砥粒数は粒子径の増加に伴い減少する が, 各粒子の 1 点にかかる荷重は増加し, そのため被 研摩材の歪みが増大する。研磨速度は, この被研摩材 の歪みに対応する砥粒の見掛けの接触断面積に依存す ると考えると, 研磨速度と粒子径の関係は 2 次式で近 似された。また，川島らは固定砥粒での加工加圧と加 工能力（ここで云う研磨速度に相当）が 1 次の直線関 係を示すことを報告している ${ }^{9)}$ 。これらの関係は以下 のように記述される。

研磨速度 $L_{\mathrm{r}}$ は, 被研摩材の歪みに対応して砥粒の 埋没断面積 $\varepsilon^{2}$ に比例すると考えられる。

$$
L_{\mathrm{r}} \propto \varepsilon^{2}
$$

ここで, 被研摩材の歪み $\varepsilon$ は, 一定荷重 $F$ 下にある 定盤亡被研摩材間に存在する砥粒の反作用力により生 じるもので, 粒子 1 個による被研摩材の圧縮応力 $\sigma$ は 粒子数 $N$ および接触断面積 $A$ から次式により与えら れる。

$$
\sigma=F /(N A)
$$

また, $N$ および $A$ と粒子径 $D_{\mathrm{p}}$ の関係は, 一定重量濃 度では次式で表わすことができる。

$$
\begin{aligned}
& N \propto 1 / D_{\mathrm{p}}^{3} \\
& A \propto D_{\mathrm{p}}^{2}
\end{aligned}
$$

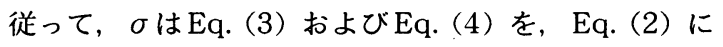
代入して次式で表わされる。

$$
\sigma=F D_{\mathrm{p}}
$$

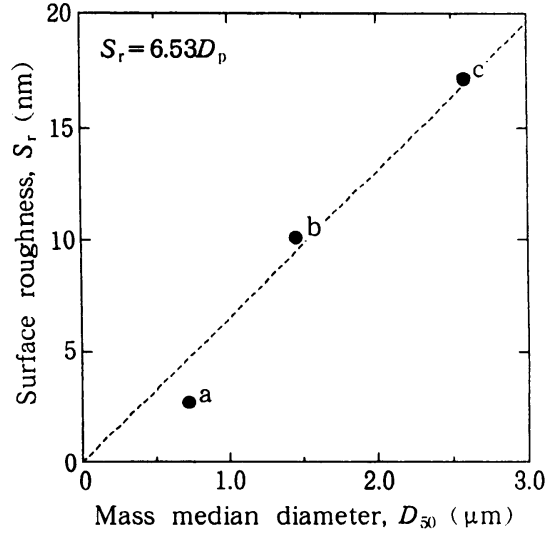

Fig. 2 Relationship between $D_{50}$ and surface roughness

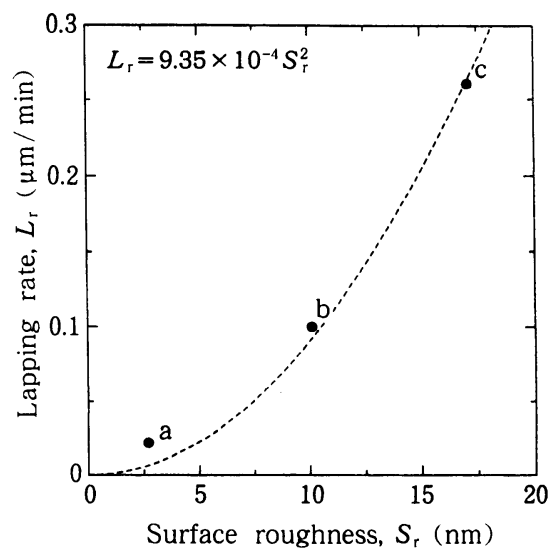

Fig. 3 Correlation between surface roughness and lapping rate

ここで被研摩材の $\sigma-\varepsilon$ の関係を 1 次式 Eq. (6) で近 似できる範囲とすると,

$$
\sigma \propto \varepsilon
$$

$L_{\mathrm{r}}$ はEq. (5), Eq. (6) をEq. (1) に代入して次式のよ うに $D_{\mathrm{p}}$ の二乗に比例することになる。そこで，実験 データを用い係数を求めると次式になる。

$$
L_{\mathrm{r}}=3.98 \times 10^{-2} D_{p}^{2}
$$

研磨面粗さ $S_{\mathrm{r}}$ は Fig. 2 に示す様に, 粒子径 $D_{\mathrm{p}}$ の増 加に伴い直線的に大きくなり 1 次式で近似できた。こ れも, 先の応力一歪みの関係に基づくものと考えら れ, 粒子径の増加に伴い, 砥粒にかかる応力は増加 し, 被研摩材の歪みも増加する。すなわち研磨面粗さ はこの歪み（砥粒の埋没深さ）に直接依存し, 砥粒粒 


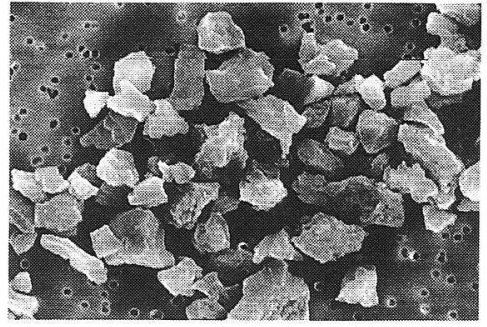

Sample A



Sample C

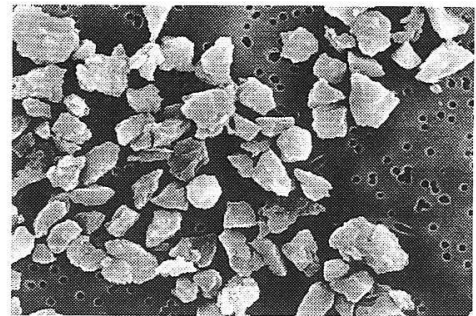

Sample B



Fig. 4 SEM photograph of different shape diamond grain

子径に 1 次で相関 ${ }^{10}$ するものと考えられる。すなわ ち, これらの関係は Eq. (5), Eq. (6) から次式のよう になる。

$$
S_{\mathrm{r}}=6.53 D_{\mathrm{p}}
$$

Fig. 3 に, 研磨速度と研磨面粗さの関係を示す。雨者 には良好な 2 次の相関関係が認められた。この関係 は, Eq. (7) およびEq. (8) から次式で表される。

$$
L_{\mathrm{r}}=9.35 \times 10^{-4} S_{\mathrm{r}}^{2}
$$

以上から，遊離砥粒の性能として粒子径の増加に伴 い, 研磨速度は上昇し, 研磨面粗さも増大寸ることが 明らかになった。これらの結果は, 固定砥粒の一般的 な研磨特性 ${ }^{11}$ とも一致するものであり, 研磨速度と 研磨面粗さは共に増大する特性を示すものである。

\section{2 粒子形状による研磨特性への効果}

被研摩材の研磨速度と研磨面粗さの関係は, 上述の ごとく粒子径と共に増大するが，市場では両特性が相 反する砥粒が要望されている。そこで，本研究におい ては, 研磨砥粒の粒子形状に着目し, 同一粒子径で研 磨速度および研磨面粗さとの関係について検討した。

\section{2.1 電子顕微鏡観察}

Fig. 4 に, 各種ダイヤモンドの SEM 像を示す。試 料 $\mathrm{A}$ は視覚的な評価において, 扁平な粒子が比較的多 く認められ，且つこれらの粒子表面には細かな凹凸が 顕著であった。試料 $\mathrm{D}$ は, 対称的且つ塊状の粒子形状
が多く認められ粒子表面は鋭利な面が顕著であった。 試料 $\mathrm{B}, \mathrm{C}$ は, 試料 $\mathrm{A}$ とDの中間的な形状を示してい た。また，いずれの試料においても，ほぼ均一な粒子 径であった。

\section{2.2 粒子径評価}

各試料の粒子径を Table 2 に示す。いずれの試料も 平均粒子径求よび $D_{25} / D_{75}$ から評価される粒度分布 の均一性も非常に高く, 粒子径に関しては, かなり高 精度な分級品であることが示された。

\section{2.3 粒子形状評価}

各種ダイヤモンドの形状指数 $k$, 粒子凹凸 $C_{\mathrm{vr}}$ を Table 2 に示す。形状指数 $k$ は, A D の順に大きな 值を示し, 視覚的な観察で認められたマクロな粒子形 状を表現していると考えられる。また，粒子凹凸 $C_{\mathrm{vr}}$ は, $\mathrm{A} \sim \mathrm{D}$ の順に小さな值を示し, 視覚的な観察で認 められた粒子表面の凹凸であるセミミクロな粒子形状 を表現していると考えられる。すなわち，A〜Dの順 に粒子形状は塊状となり，且つ表面の凹凸は減少する ことが定量的に示された。

\section{2.4 形状指数と研磨速度の関係}

形状指数 $k$ 之粒子凹凸 $C_{\mathrm{vr}}$ は本質的には独立因子で あるが，実際には関連している場合もある。本研磨速 度の実験デー夕は，それぞれ $k ， C_{\mathrm{vr}}$ の值にお互いの 効果を含むことから, 全ての実験デー夕を用い最小二 乗法により研磨速度 $L_{\mathrm{r}}$ に対する $k ， C_{\mathrm{vr}}$ のベキを決定 した。その結果がEq. (10) である。 


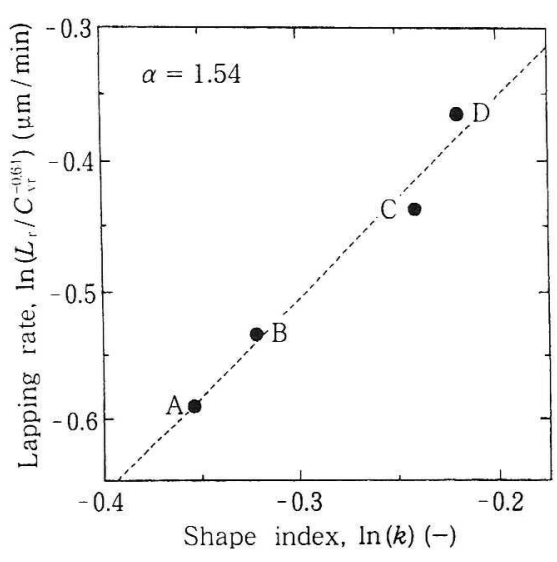

Fig. 5 Relationship between shape index and lapping rate

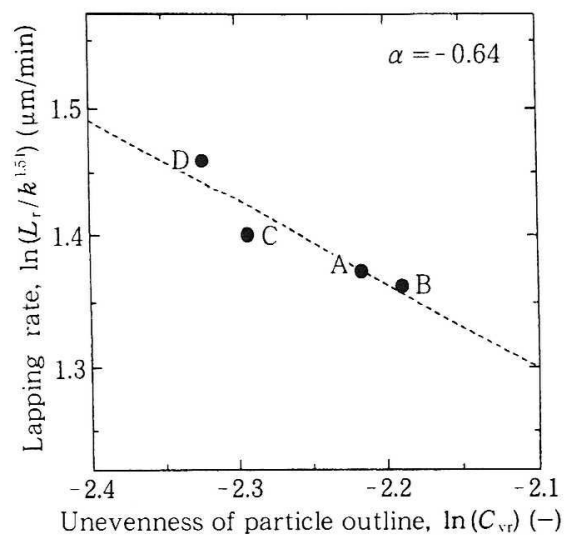

Fig. 6 Relationship between unevenness of particle outline and lapping rate

$$
L_{\mathrm{r}}=0.96 k^{1.54} C_{\mathrm{vr}}^{-0.64}
$$

研磨速度 $L_{\mathrm{r}}$ と形状指数 $k$ の関係を Fig. 5 に示した。 $k$ の増加に伴い $L_{\mathrm{r}}$ は増加し, 粒子形状としては, マ

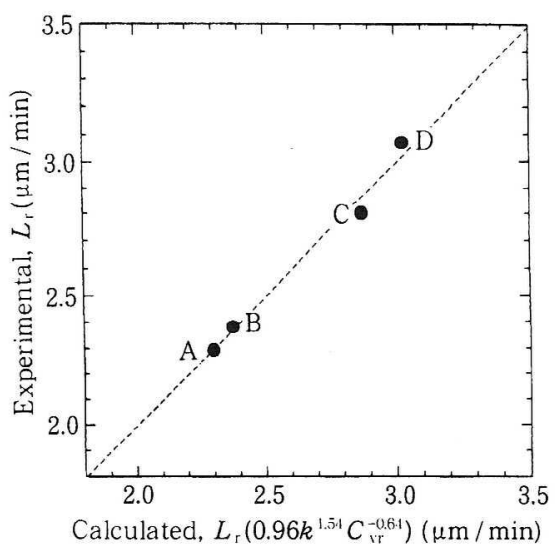

Fig. 7 Comparison of calculated lapping rate with experimental one

クロには塊状粒子が有效であると考えられる。Fig. 6 に粒子叫凸 $C_{\mathrm{vr}}$ と研磨速度 $L_{\mathrm{r}}$ の関係を示す。 $C_{\mathrm{vr}}$ の 減少に伴い， $L_{\mathrm{r}}$ は增加し，セミミクロな粒子形状と しては，粒子表面の凹凸の少ないものが有効であるこ

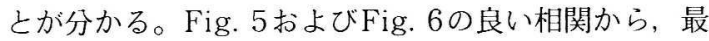
小二乗法で求めた $k, C_{\mathrm{vr}}$ のベキの妥当性が認められ た。これらの結果, 研磨速度に及ぼす粒子形状の効果 は形状指数 $k$ 及び粒子山凸 $C_{\mathrm{vr}}$ の雨者が関与してお り，研磨速度には粒子径に加え，Eq. (10) に示され る様に形状指数が大きく関与し，マクロな形状の影響 が大きいことが分かった。

Fig. 7 に，研磨速度の実験值と計算値を示す。図に 示される様に，両者の相関性は比較的高く，実験式の 妥当性が明らかとなり，粒子形状を評価することによ り研磨速度の推定が可能と考えられた。

Fig. 8 に, 試料 A および試料Dの単一モデル粒子を 示す。上記条件を満たす試料 Dは, 試料 A と比較し て, 研磨速度において約 $30 \%$ の向上が認められた。

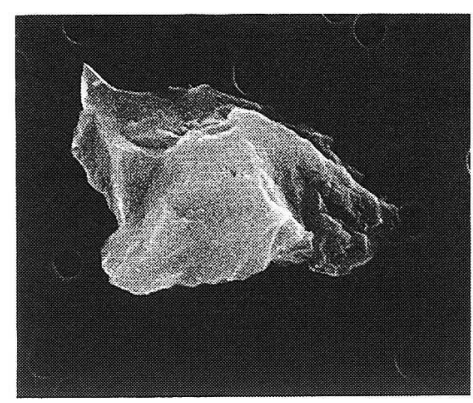

Sample A

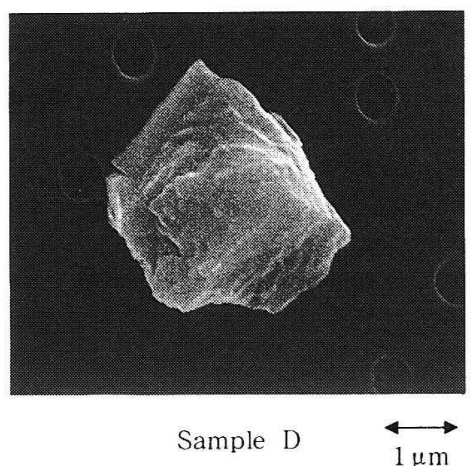

Fig. 8 SEM photograph of sample A and sample D 
研磿速度に粒子径以外の形状指数が影響する理由の つとして, 研磨過程における砥粒の運動が関与し ていると考えられる。特に寄与率の高い $k$ について は, 近似楕円の短軸と長軸との比を評価しており, Eq. (9) から研磨速度の低下は短軸と長軸の比が減少 するもの，すなわち扁平粒子へと近づくものである。 この様な粒子形状は, 定盤と被研摩材間において, 塊 状粒子がランダムに運動し粒子が頻繁に研磨機能を発 揮するのに対して，その運動方向に制限があり研磨頻 度を下げるものと推察される。

また，原理的には $k=1$ で $C_{\mathrm{vr}}=0$ の完全球形粒子 では，ほとんど研磨性能は期待できないことから，

Eq. (10)における $L_{\mathrm{r}}$ の最大值にはおのずと限界があ り， $C_{\mathrm{vr}}$ には最小值があり, さらに研磨速度に及ぼす よりミクロな形状特性の存在が示唆された。しかし, 本研究の巨視的な取り扱いでは，そこまでの精度は検 討できなかった。

\section{2.5 形状指数と研磨面粗さの関係}

Fig. 9に, 形状指数と研磨面粗さの関係を示す。各

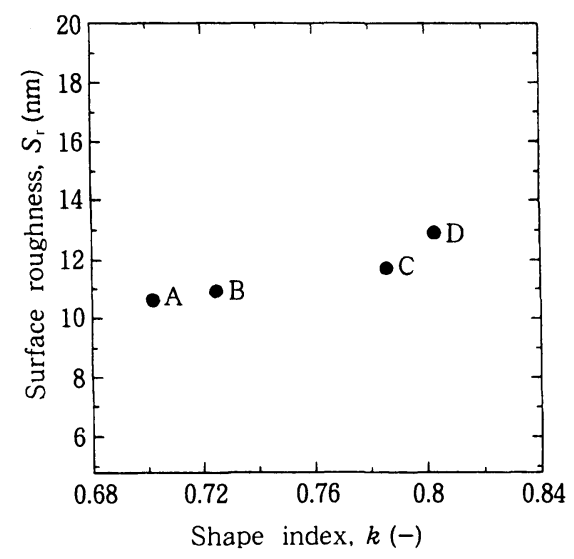

Fig. 9 Relationship between shape index and work surface roughness
試料について研磨面粗さには有意な差は認められず, Eq. (7) 及びEq. (8) より $k$ に関しては 0.5 乗を示す。 また， $C_{\mathrm{vr}}$ についても式からその寄与率は高くない。 この様な結果から, 被研摩材の表面粗さには, マクロ な形状およびセミミクロな形状は影響せず，先の 3.1 項で述べた粒子径のみに依存すると考えられる。

\section{4. 結言}

精密研磨加工に用いられる多結晶ダイヤモンドの研 磨特性として, 被研摩材の研磨速度および研磨面粗さ に及ぼす粒子径と粒子形状の効果について，実験によ り検討し以下の知見を得た。

1)研磨砥粒の研磨特性は, 被研摩材と砥粒間における 応力ー歪み関係で理解でき, 粒子径とともに研磨速 度および研磨面粗さは増大し, 望まれる研磨性能と しては相反する特性であることが分かった。また粒 子径と研磨速度は 2 次の関係を, 研磨面粗さは 1 次 の関係を示した。

2）第 1 次フーリエ記述子に基づく形状指数 $k$ および 粒子凹凸 $C_{\mathrm{vr}}$ から, 砥粒の粒子形状之研磨特性との 良好な相関が得られた。

3) 形状指数より研磨速度に関する実験式が得られ, 粒子形状から研磨速度の推定が可能となった。

4）研摩材の性能は，これまで主に研摩材の粒子径に 依存すると考えられてきたが，マクロな粒子形状の 寄与もかなり大きく，粒子形状を制御することによ り, 同一粒子径で, 研磨面粗さはほぼ同等, 且つ研 磨速度の高い砥粒の製造が可能であることが分かっ た。

[謝辞] 本研究の一部は, 平成 9 年科学技術振興財団 の「コンセプト・モデル化事業」により推進したもの である。また，本研究をまとめるにあたり，北海道立 工業試験場資源エネルギー部省資源プロセス科長㝨嶋 裕典氏, 同研究員松嶋景一郎氏には大変有益なご助言 を頂きました。ここに記し謝意を表します。

\section{Nomenclature}
$A$ : apparent contact area of lapping particle $\left(\mathrm{m}^{2}\right)$
$k$ : shape index by short to long axis of ellipse (-)
$C_{\mathrm{vr}}$ : coefficient of variation of distance from particle
$N$ : number of particles
$(-)$ centroid to its outline
$(-)$
$L_{\mathrm{r}}$ : lapping rate
$(\mu \mathrm{m} / \mathrm{min})$
$S_{\mathrm{r}}$ : surface roughness
( $\mathrm{nm}$ )
diffraction method
$(\mu \mathrm{m})$
$\sigma$ : normal stress
$\left(\mathrm{N} / \mathrm{m}^{2}\right)$
$D_{\mathrm{p}}$ : particle diameter
$\varepsilon \quad$ : strain
$(-)$
$F$ : lapping load
(N) 


\section{References}

1) Tanaka, T., Y. Takayama and K. Ono: "Spheriforming Treatment of Metal Powders by Dry Impact Blending Preparation”, ZAIRYOU GIJYUTU, 6, 260269 (1988)

2 ) Oshima, T., Y. L. Zhang, M. Hirota, M. Suzuki and T. Nakagawa, :The Effect of the Types of Mill on the Flowability of Ground Powders", J. Soc. Powder Technol., Japan, 30, 496-501 (1993)

3 ) Otani, M., T. Uchiyama, H. Minoshima, K. Shinohara, K. Takayashiki and N. Nakao: "Factors on Particle Shape Control by Dry Impact Blending Method", J. of the Soc. of Mat. Eng. for Resources of Japan, 7. 35-45 (1994)

4 ) Otani, M., H. Minoshima, T. Ura and K. Shinohara : "Mechanism of Particle Shape Modification by Dry Impact Blending", Adv. Powder Technol., 7, 291-303 (1996)

5 ) Otani, M., Y. Uchiyama, K. Arahori and K. Shinohara : "The Preparation of Differently Shaped Particles by Grinding", J. Soc. Powder Technol., Japan, 34, 432-436
(1997)

6 ) Otani, M., H. Minoshima, T. Uchiyama, K. Shinohara, K. Takayashiki and T. Ura: "The Effect of Particle Shape on the Mechanical Properties of Powder Bed”, J. Soc. Powder Technol., Japan, 32, 151-157 (1995)

7 ) Otani, M., H. Minoshima, W. Hino, K. Shinohara : "Wall-Friction Characteristics of Differently Shaped Particles", J. Ceramic Soc. Japan. 105, 1099-1102 (1997)

8 ) Imanaka, O.: "Studies on Lapping of Glass", Denkisikensho Ihou, 25, 337-345 (1961)

9 ) Kawasima, N. : "Application of Lapping Films in Precision Processing” Shikizai, 66, 476-486 (1993)

10) Kawasima, N., T. Hattori and S. Tochihara, : "Lapping Film for Hard Disk Texturing", ZAIIRYOU GIJYUTU, 9, 300-305 (1991)

11) Suzuki, K.: "The Performance of Micron Size Diamond Powder", ZAIRYOU GIJYUTU, 9, 294-299 (1991) 